\title{
JUDGING RULES, RULING JUDGES
}

\author{
StePhen C. YeAZELL* \\ । \\ INTRODUCTION
}

We conventionally and correctly observe that the Federal Rules of Civil Procedure are widely admired and imitated. This observation makes it tempting to conclude that the process producing those rules must be working reasonably well. U nfortunately, the second proposition does not follow from the first. Substantial changes in the structure and personnel of rulemaking have occurred in the sixty years since the R ules were first promulgated. The present-day Rules may be living off their intellectual capital rather than renewing or increasing our store of procedural wisdom. To make matters worse, most arguments about the rulemaking process in recent decades-arguments that are taking an increasingly rancorous tone-have been about the relative roles of the judiciary and the legislature. That frames the wrong debate. We should be talking instead about why we have bureaucratized and complicated what began as a nearly private and relatively simple enterprise. B ureaucracy and complexity are not pejorative terms, but they are limiting terms, and it makes sense to examine the limitations that inhere in them.

We can rescue most of the threatened virtues of the federal rulemaking process by taking two steps, one intuitive but politically difficult, the other counterintuitive and also politically difficult. First, we should reduce the encrustation of steps in the process, returning it to essentially two steps before presentation to Congress. Second, we need to change the role of judges in the process. O ver fifty years we have moved the judiciary from its original and appropriate role-arbiter of the ultimate fairness of proposed rules-to that of initial drafters of the rules. A II manner of ill consequences have flowed from this shift, not the least of which has been an increase of clashes with Congress. A short way of capturing this change is to say that we need to return from a system of judicially created rules back to a system of judicially scrutinized rules. $M$ aking the case for this change is not difficult, however difficult its effectuation may prove.

\footnotetext{
Copyright (c) 1998 by L aw and Contemporary Problems

This article is also available at http://www.law.duke.edu/journals/61L CPY eazell.

* Professor of L aw, U niversity of California at L os A ngeles.

I am grateful to Paul Carrington, J udith R esnik, and D avid L. Shapiro for comments on an earlier draft.
} 
II

\section{A MBIVALENT BENTHAMITES}

A Imost two centuries ago J eremy Bentham argued that almost everything wrong with procedure could be attributed to "Judge and Company." 1 A s B entham saw it, judicially created procedure, endemic to the common law, was also its bane. N ever one to take a measured view of anything, B entham attributed all procedural evil to guild self-interest: Judges, former lawyers who consorted with lawyers and who derived income from fees, had created a system benefiting only judges and lawyers. B entham saw a vast, if unconscious, conspiracy to create complexity from simplicity, and viewed procedural rules as professional featherbedding. $Y$ et, B entham did not recommend legislation, his usual panacea, for procedural rules. Though Bentham hated judge-made rules, he recommended judge-made procedure. Proposing to abolish all standing rules and forms, he wanted to substitute for them a judicially controlled, but ad hoc, open-textured, untechnical procedure modeled on a wise parent presiding over family disputes. ${ }^{2}$

To judge by the current procedural system, we cannot decide whether to heed or shun Bentham's advice. On one hand, in the federal system judges do make the procedural rules, and no one would describe the present system as being without forms and rules. On the other hand, the flexibility of the Federal $R$ ules combines with the large power vested in the district court judge and creates broad discretionary procedural power that to some might seem analogous to B entham's judicial parent. A s with parents, in the hands of a master, such discretion may create a procedural heaven; in the hands of the inept, inexperienced, or misguided judge, a procedural hell is more likely.

O ne can understand much contemporary procedural debate as an unconscious commentary on our approach to Bentham. For some, the transition from eighteenth-century to $\mathrm{V}$ ictorian parenting was itself a great mistake. For them, L ord C hesterfield, with his stern but clear rules, was greatly preferable to the formless sentimentality that makes the dysfunctional M r. D ombey as likely as the wise B etsy Trotwood. ${ }^{3}$ For others, the move from rules to discretion was either laudable or inevitable, but the desirable style of parenting is very much at issue. ${ }^{4}$

1. C.J.W. A LLEN, The LAW OF EVIDENCE In ViCtorian ENGLAND 54 (1997).

2. See id. at 9-10.

3. Stephen Subrin is perhaps the clearest in this respect. See generally Stephen Subrin, Fishing Expedition: The Historical Background of the 1938 Federal Discovery Rules, 39 B.C. L. REV. 691 (1998); Stephen Subrin, H ow Equity Conquered the Common L aw: The Federal Rules of Civil Procedure in H istorical Perspective, 135 U . PA. L. REV. 909 (1987). The parental models mentioned in the text refer to PHILIP D ORMER STANHOPE, FOURTH EARL OF CHESTERFIELD, 1694-1773, LeTTERS TO HIS SON AND OTHERS (E.P. Dutton 1929); CHARLES DICKENS, D OMBEY A ND SON (1848); CHARLES DICKENS, DA VID COPPERFIELD (1850).

4. Judith Resnik's work contains a number of distinguished examples. See, e.g., Failing Faith: Adjudicatory Procedure in Decline, 53 U.CHI. L. REV. 494 (1986); Changing Practices, Changing Rules: Congressional Rulemaking on Civil Juries, Civil J ustice, and Civil J udging, 49 A LA . L. REV. 133 (1997). 
A s with many similarly inconclusive debates, it may be helpful to reflect on the process by which we got to this point. Bentham attacked a processjudicial framing of procedural rules-and espoused a substantive result-broad judicial discretion. We have embraced both the process B entham despised and the result he advocated, adopting a system in which judges draft rules that bestow broad discretion on judges. M oreover, we have over the last fifty years moved from a relatively flat process of proposal and promulgation to a multitiered system of consultation, review, and revision by multiple committees.

In this newer world, we should listen carefully to Bentham's caution about judicial domination of rulemaking, though for a reason nearly the opposite of his. Bentham feared that judicial domination of procedure would serve mostly to raise lawyers' and judges' fees. ${ }^{5} \mathrm{He}$ feared that procedural designers and procedural consumers were all too closely joined. I have the opposite concern-that contemporary judicial domination of rulemaking isolates procedural designers, who today are mostly judges, from procedural consumers-lawyers and litigants. ${ }^{6}$ If isolation from the bar is one feature of contemporary rulemaking, the other is an apparent opposite: diffusion of responsibility. Because so many people and so many layers are involved in rulemaking, in a broader sense, no one is in charge. ${ }^{7}$

When combined, isolation of rulemakers and diffusion of rulemaking authority threaten both judicial independence and judicial accountability. They threaten independence because a judicially dominated rulemaking process is more likely to produce faulty rules and, just as important, rules perceived to be faulty. Faulty rules will inevitably produce either controversy or legislative action-both undermining judicial independence. I solation and diffused authority also threaten accountability: A ny quasi-legislative system in which no person or body has responsibility for a legislative agenda is likely to produce paralysis rather than reform.

These features-isolation and diffusion-threaten especially bad results under contemporary circumstances. In 1938, most procedure occurred in

5. In B entham's day, judges were still paid by fees collected on a per-motion basis, so any procedural ruling that generated the possibility of a motion or hearing carried with it the potential for increased judicial income.

6. There is some evidence to suggest that it is difficult for judges to keep litigation costs in mind when designing procedures. A recent study of judicially designed case management processes suggests that the result was increased cost to litigants. See J ames S. K akalik et al., J ust Speedy and I nexpensive? A $n$ E valuation of J udicial Case M anagement Under the Civil J ustice Reform A ct, 49 A LA . L. REV. 17, 18 (1997) ("E arly judicial case management also is associated with significantly increased costs to litigants."). The irony of this finding is that the A ct in question was itself a congressional response to dissatisfaction with existing judge-made rules.

7. Some recent literature has recognized this diffusion and has recommended that rulemaking be driven by a "chancellor," who would assume central responsibility for the rulemaking process (as well as other administrative tasks). See generally R USSELLR. WhEELER \& GORDON BERMANT, FEDERAL COURT GOVERNANCE: Why CONGRESS SHOULD-AND Why CONGRESS SHOULD NOT-CREATE A Full-Time ExeCutive Judge, A bOLISH the Judicial CONFEREnCE, and Remove CiRCUIT JUDGESFROM DISTRICT COURT GOVERNANCE (1994). If added to the present system, this proposal constitutes another undesirable complexity. If added in conjunction with the much simpler system suggested below in the text, it seems likely to be unnecessary. See infra Part IV . 
courtrooms, visible to judges, as well as to lawyers. E very trial judge knew how procedural rules worked in practice- he saw them on a daily basis. Today, most procedural events happen outside the view of the A rticle III judges who dominate rulemaking-in depositions, settlement negotiations, and in magistrate judges' chambers. ${ }^{8}$ This invisibility renders judges blind to the workings and possible consequences of some procedural rules. It may have the further effect of inducing more confidence than is justified about those practices that occur within the judicial range of vision. Over the past fifty years, we have moved the location of rulemaking authority deeper into the judiciary even as we moved the focus of procedure farther from the courtroom. The next section chronicles the changes.

\section{III}

\section{The Changing Structure and Personnel of Rulemaking}

J udicial rulemaking is broader than the Federal $\mathrm{R}$ ules, ${ }^{9}$ but the most visible and influential judicial rulemaking has been federal. Since $1934,{ }^{10}$ the Supreme Court has had the power to make "general rules of practice and procedure." B ut, since 1934, nearly every important characteristic of the rulemaking process has changed. E ach change has been small. E ach change has been understandable. But many changes have been regrettable.

In 1938, the original Advisory Committee, appointed by Chief Justice $\mathrm{H}$ ughes, presented the Rules of Civil Procedure to the Court, which promulgated that draft. No judges sat as members of that original advisory committee. Since that time, we have added between two and nine layers of rulemaking ${ }^{12}$ and have increased judicial participation in the drafting process to the point of domination. Whether these changes have produced a more thoughtful or a more responsible process is doubtful. A brief sketch may make the point.

\section{A. Process}

In a short paragraph, the original R ules E nabling A ct gave the rulemaking power to the Supreme Court. ${ }^{13}$ The minutes of the next meeting of the J udicial

8. I am here loosely defining a procedural event as an activity undertaken by a lawyer in connection with a lawsuit. It could be a court appearance, a conversation with the opposing side, or a settlement conference with a judge.

9. Somewhat heroically, the Supreme Courts of New Jersey and Wyoming have discovered that their respective constitutions give those tribunals exclusive power to make rules of practice and procedure and thus negate legislative acts that conflict with court-made rules. See W inberry v. Salisbury, 74 A .2d 406, 414 (N.J . 1950) (invalidating legislation that extended the time for appeal beyond that permitted by court-made rules); White v. Fisher, 689 P.2d 102, 103 (Wyo. 1984) (invalidating statute prohibiting statement of dollar figure in ad damnum clause of medical malpractice complaint).

10. See A ct of J une 19, 1934, Pub. L. N o. 73-415, 48 Stat. 1064 (codified as amended at 28 U S.C. $\S \S 2071-2077$ (1994)). The original Federal R ules of Civil Procedure did not take effect until 1938.

11. 28 U .S.C. § 2072 (1994).

12. The range depends on one's criteria for a layer of rulemaking.

13. See 28 U.S.C. $\$ 2072$ (1994). The second, and only other, paragraph of the A ct authorized the judicially promulgated rules to merge law and equity, a power of which the new R ules of Civil Proce- 
Conference, convened in September of 1934, contained an earnest solicitation for the "cooperation of the members of the Bench and Bar throughout the country" in the "discharge of this highly important and difficult task." ${ }^{14}$ The Supreme Court appointed an A dvisory Committee, which four years later presented a draft to the Court.

The resulting $\mathrm{R}$ ules are history. In the short run, they merged law and equity and abolished technical pleading. In the long run, they have transformed civil litigation. The Rules and their state analogues ${ }^{15}-$ by creating deep and broad discovery, by expanding joinder, by extending the pretrial phase of litigation, and by taking that phase largely out of the courtroom and into lawyers' offices-have reshaped civil procedure.

Though it is always dangerous to capture subtle changes in catch phrases, one can summarize many of the changes by noting that in recent decades we have seen the emergence of a distinction between "trial lawyers" and "litigators" and between "trying" and "managing" cases. ${ }^{16}$ These distinctions would have made no sense to the lawyers who drafted the original Federal Rules. Then, as now, most cases ended before trial, but for the one case in three that did not settle, trial was the likely destination. ${ }^{17}$ A s a result, most "procedural events" occurred before judicial eyes.

For several decades after the R ules' adoption, one might have thought that they had inaugurated procedural perfection, for few amendments were proposed or accepted. Then came three major waves of change, in 1966 (affecting parties' practice), 1970 (discovery), and 1983 (the etiquette and ritual of pretrial practice). Some of these changes proved controversial, either in anticipation or practice. O rdinarily mild-mannered lawyers can become wildly enthusiastic or deeply unhappy at the mention of the modern class action, introduced by the 1966 amendments. We are continuing to debate whether expanded discovery, a product of the 1970 changes, has proved a boon or bane. The 1983 version of R ule 11, after inspiring enough writing to launch several academic careers, was defanged ${ }^{18}$ a decade later, providing-depending on one's point of

dure took notorious advantage. See Subrin, H ow E quity Conquered the Common L aw, supra note 3, at 922.

14. A dministrative Office of the United States Courts, Report of the Judicial CONFERENCE 8 (Sept. 1934).

15. The Rules have deeply influenced U.S. procedure, both in the thirty-five states that have formally adopted some version of the Rules as their procedural regime, see generally J ohn B. Oakley \& A rthur F. Coon, The Federal Rules in State Courts: A Survey of State Court Systems of Procedure, 61 W A SH . L. REV . 1367 (1986), and also in those, like California and N ew Y ork, that have remained Code states while adopting the essential characteristics of the federal model. See id. at 1383, 1411.

16. See generally Samuel G ross \& K ent Syverud, D on't Try: Civil J ury Verdicts in a System G eared to Settlement, 44 U CLA L. REV. 1 (1996); Judith Resnik, From "Cases" to "Litigation", 54 LAW \& CONTEMP. PROBS. 5 (Summer 1991).

17. Stephen C. Y eazell, The M isunderstood Consequences of M odern Civil Process, $1994 \mathrm{WIS}$. L. REV. 631, 633 (reporting a drop in civil cases resolved by trial from about $20 \%$ in 1938 to about $4 \%$ in 1990).

18. The 1993 amendments substantially decreased the risk of violating R ule 11 . First, they provided for a "safe harbor," requiring notice by the opponent and a 21-day period in which to retract or amend the offending document without penalty. See FED.R.CIV.P. $11(C)(1)(A)$. It is hard to imagine 
view-either an example of too-long-delayed justice or of judicial pusillanimity in the face of an obstreperous bar.

A final example of a nonchange is the more recent experience involving R ule 48. In 1973, the U.S. Supreme Court decided Colgrove v. Battin, ${ }^{19}$ which validated the use of six-person juries in civil cases. It did so at a catastrophically bad time, as legislation and other developments were changing the demographic characteristics of the jury by insisting on cross-sectionality. Since Colgrove, a considerable body of respectable writing has demonstrated that the smaller jury makes broad demographic representation harder to achieve and erratic variations in verdicts more likely. ${ }^{20}$ A ccordingly, in 1996, the Civil R ules committee proposed an amendment to R ule 48, making clear that twelve ought to be the normative size of the jury. ${ }^{21}$ The amendment was approved both by the R ules Committee and the Standing Committee, but was rejected by the J udicial Conference in an almost hasty way, in part because of objections that in the time since Colgrove many federal courtrooms with too-small jury boxes had been built. ${ }^{22}$ This is not the way to make procedural rules.

A ccompanying these substantive changes (if one can so describe alterations in rules of procedure) were two parallel developments-in the complexity and in what one might call the legitimacy of the rulemaking process. The original Rules Enabling A ct spoke of only two layers of rulemaking: the Supreme Court, which promulgated the Rules, and Congress, which could override a Rule. $^{23}$ In practice, the process had only one significant step: The A dvisory Committee played the major role, with the Court and Congress presiding but not interfering. Nor did the present-day Standing Committee on Rules and Practice exist.

that this change will not result in some litigative games of "chicken," with lawyers making dicey statements with the knowledge that they will have a second chance. Second, the amended rule contains a mysterious provision allowing allegations for which there is no present factual basis if the party is "likely" to find such support in discovery. See FED. R. CIV. P. 11(b)(3). Finally, the amended Rule removes attorneys' fees as the presumptive sanction for a violation, thus substantially decreasing the opposing party's incentive to bring a suspected violation to the court's attention. See FED. R. CIV. P. $11(c)(2)$.

I take no position here about the desirability of these changes. M any voices have argued that the 1983 version of the Rule, at least in practice and perhaps in conception, operated unevenly, penalizing civil rights plaintiffs much more harshly than others. See Stephen Burbank, The Transformation of A merican Civil Procedure: The Example of Rule 11, 137 U. PA . L. REV. 1925, 1938 (1989). M y point about the 1993 amendments is that they suggested that the A dvisory Committee thought a R ule less than a decade old had serious defects.

19. 413 U .S. 149 (1973).

20. The evidence is devastatingly summarized in R ichard S. A rnold, Trial By J ury: The Constitutional Right to a J ury of Twelve in Civil Trials, 22 H OFSTR A L. REV. 1, 30 (1993).

21. J udith R esnik's account in Changing Practices, Changing Rules, supra note 4, at $136-46$, is both concise and telling.

22. Interview with Paul Carrington, Professor of $L$ aw, Duke U niversity School of $L$ aw (A pr. 13, 1998); Telephone Interview with the Honorable Patrick Higginbotham, Circuit Judge, Fifth Circuit (O ct. 8, 1998); see also Stephen B. B urbank, Implementing Procedural Change: Who, How, Why, and When?, 49 A LA L. REV. 221, 244 (1997).

23. A ct of J une 19, 1934, Pub. L. No. 73-415, 48 Stat. 1064 (codified as amended at 28 U.S.C. §§ 2071-2077 (1994)). 
Today's process is, of course, quite different. It requires more steps to amend a Federal R ule of Civil Procedure ${ }^{24}$ than it does to amend the U.S. Constitution. A s described by a former R eporter to one of the A dvisory Committees, amending a Federal $\mathrm{R}$ ule of Civil Procedure requires a dozen consultations, proceeding from public and bar suggestions to the A dvisory Committee, to the Reporter, to various academic and bar organizations, back to the A dvisory Committee, to the Standing Committee, back to the A dvisory Committee, to public hearings, back to the A dvisory Committee, again to the Standing Committee, to the Judicial Conference, to the Supreme Court, and thence to Congress. $^{25}$ "Cumbersome," the adjective used by one close observer, ${ }^{26}$ seems a quite measured comment.

Slowness need not be a vice, if the resulting product is satisfactory. This essay is not the place for an assessment of the success of recent Federal R ules. O ne can say that in the last three decades, new rules have engendered substantial controversy. It has been controversy that has reached beyond the profession's usual resistance to change. The "retraction" of R ule 11 after a decade's experience provides one illustration, the scuttling of Rule 48 another. Continuing concern with the class action suit and with discovery provide further examples. Several have posited that "trans-substantivity" - neutral application across fields of substantive law-is a desirable characteristic of procedural rules. $^{27}$ Invisibility is another: To the extent that debates about process displace debates about substantive law, the procedural system is not working optimally. The civil R ules have become more controversial over the last few decades, and that ought to alert us to look carefully at the system that has produced this visibility. ${ }^{28}$

This era of controversy began in 1973, when Congress rejected in their entirety the proposed Federal Rules of Evidence. ${ }^{29}$ Privileges lay on the surface of the dispute, but underneath the specific issues lay some congressional unrest

24. In this essay, I shall focus on the R ules of Civil Procedure, in part because I know them best, and in part because in recent years their amendment has aroused the greatest controversy. The two most notable exceptions to this proposition are the Federal $\mathrm{R}$ ules of $\mathrm{E}$ vidence, whose first incarnation Congress rejected in its entirety because of disagreements with their treatment of privileges, and the B ankruptcy R ules, controversy over which mostly flowed from the contested constitutional position of the $B$ ankruptcy Judges. J udging by congressional interest, the Federal R ules of Criminal Procedure have not aroused the same level of controversy.

25. See Paul Carrington, M aking Federal Rules to D ispose of $M$ anifestly U nfounded A ssertions: A n Exorcism of the Bogy of Non-Trans-Substantive Rules of Civil Procedure, 137 U. PA. L. REV. 2067, 2120-23 (1989).

26. Telephone Interview with the Honorable Richard S. A rnold, Circuit Judge, Eighth Circuit (O ct. 6, 1998).

27. Compare R obert Cover, For James Wm. Moore: Some R eflections on Reading the Rules, 84 YALE L.J . 718, 718 (1975) (arguing for differential application of rules to differing kinds of cases), with C arrington, supra note 25, at 2068 (arguing against such a course).

28. To forestall misunderstanding, readers should understand that the process used to produce rules should be visible, open, and transparent. See infra Part V.A.2. The resulting rules themselves, however, should optimally be invisible because they are uncontroversial. This form of procedural invisibility may be impossible to reach, but it is a noble aspiration.

29. See A ct of M arch 30, 1973, Pub. L. N o. 93-12, 87 Stat. 9. 
at what was perceived to be high-handedness in proposing and promulgating Rules. That unrest had two components. First, any legislature will occasionally be uneasy about a delegation of power. That unease will be at its height when the delegated authority seems to be exercised in inappropriate ways, as with the proposed evidentiary rules. $^{30}$ Second, Congress had been hearing from some lawyer-constituents that the rulemaking process was insufficiently open to commentary, particularly critical commentary, from affected persons. Stephen Burbank's account of the decades-long development perceptively notes that the judiciary's greatest loss may have come in a battle that it nominally won. In 1983, the H ouse of R epresentatives voted to block implementation of R ule 11. O nly the adjournment of the Senate prevented what would likely have been the defeat of the R ule. Burbank argues that the promulgation of a Rule in the face of so much political opposition did the judiciary great harm in its relations with Congress, creating a "poisonous environment."

Congress responded in two ways, with criticism and with statutory change. The statutory change added time, open deliberation, and more layers to the rulemaking process. Specifically, the 1988 Judicial Improvements and A ccess to J ustice $A \mathrm{Ct}^{32}$ formally required the system of advisory committees reporting to a standing committee on rules of practice and procedure, and likewise formally inserted the Judicial Conference itself into the process of rulemaking. ${ }^{33}$ The result is procedure's very own twelve-step program.

Congress reflected its continuing dissatisfaction two years later, with the Civil J ustice Expense and Delay Reduction Plan of $1990 .{ }^{34}$ That A ct encouraged and required procedural experimentation at the district court level, permitting individual districts to adopt procedural rules departing from the Federal R ules in various respects, including a "tracking" system that would subject cases to differing procedural rules depending on their characteristics. In the same year Congress took the unusual step of debating a set of proposed changes in discovery rules, suggesting continuing restiveness. ${ }^{35}$ Stephen Bur-

30. The original draft of the Federal Rules of $E$ vidence proposed federalization of privileges and the consequent abrogation and supplementation of state evidentiary privileges in federal court litigation. Whatever might be said on the merits about such a course of action, to propose it without hearing, notice, and preparation was at least ill-advised and arguably in violation of the Rules Enabling A ct.

31. See B urbank, supra note 22, at 228.

32. Pub. L. N o. 100-702, 102 Stat. 4643 (1988) (codified in scattered sections of 28 U .S.C.).

33. 28 U .S.C. $§ 2073$ (b) (1994). The statute requires that the J udicial Conference appoint standing and advisory committees and that the standing committee "recommend to the J udicial Conference... such changes in rules proposed by a committee appointed [by the Conference]." Id. The statute does not explicitly say that the Conference's approval is necessary for a prospective rule to be forwarded to the Supreme Court for promulgation. But the preexisting practice, reinforced by the statutory language, has continued, thus de facto making the Conference's approval necessary for a rule to be sent to the Supreme Court.

34. See Civil J ustice R eform A ct of 1990, Pub. L. N o. 101-650, 104 Stat. 5089 (codified at 28 U .S.C. $\S \S 471-482(1994))$.

35. The proposed amendments passed by overwhelming margins (99-1 in the Senate and unanimously in the House). The noteworthy event is not that the proposed amendments passed, but that they were debated in Congress. See id. 
bank's judgment that "[i]t is difficult ... not to sense a crisis in federal procedural reform" ${ }^{36}$ seems close to the mark.

\section{B. Personnel}

As the procedure has become more cumbersome, the personnel have changed. Where lawyers once wrote the Rules and presented them to the bench for a blessing, judges now dominate the process. A s already noted, the advisory committee that drafted the 1938 Rules had no judicial members; it consisted entirely of lawyers and legal academics. ${ }^{37}$ Today judges comprise a bit more than half of the A dvisory Committee and Standing Committee, and all of the J udicial Conference. L awyer participation has declined as that of judges increased. Today, lawyers comprise just a bit more than a third of the members of the A dvisory Committee on Civil R ules. The tide had begun to shift in this direction within two decades after the original Rules were enacted. In 1961, just over half of the A dvisory Committee's members were practicing lawyers; that proportion held through the early 1980s. By 1985, the proportion had dropped to about twenty-five percent; over the last few years it has hovered between thirty-three and forty percent. The Committee that submitted the most recent proposed changes in the R ules of Civil Procedure consisted of fourteen members, five of whom were practicing lawyers-if one includes the A ssistant A ttorney $G$ eneral of the Civil Division in this category. Seven are judges- six of these from the federal courts and one from a state court. The remaining two members are legal academics. ${ }^{38}$ The proportion of lawyers on the Standing Committee, a body that had no analogue in 1938, is similar. ${ }^{39}$ A nd of course the Judicial Conference, which now passes on the proposed rules before their submission to the Court, consists entirely of judges. So, during the same time in which we have increased the layers of bureaucratic apparatus from two to twelve, we have moved from a system dominated by lawyers to one dominated by judges.

36. Stephen B. Burbank, Ignorance and Procedural Law Reform: A Call for a Moratorium, 59 BROOK. L. REV. 841, 842 (1993).

37. See Carrington, supra note 25 , at 2119.

38. See Committee on Rules of Practice and Procedure of the Judicial Conference of the United States, Preliminary Draft of Proposed amendments to the Federal RULES OF CIVIL PROCEDURE AND EVIDENCE 150 (1998).

39. Five of the 16 members, or $31 \%$, of the Standing Committee on R ules of Practice and Procedure are practicing lawyers, again including the Department of J ustice member in that category. See id. at 149. 
Composition of the Advisory Committee

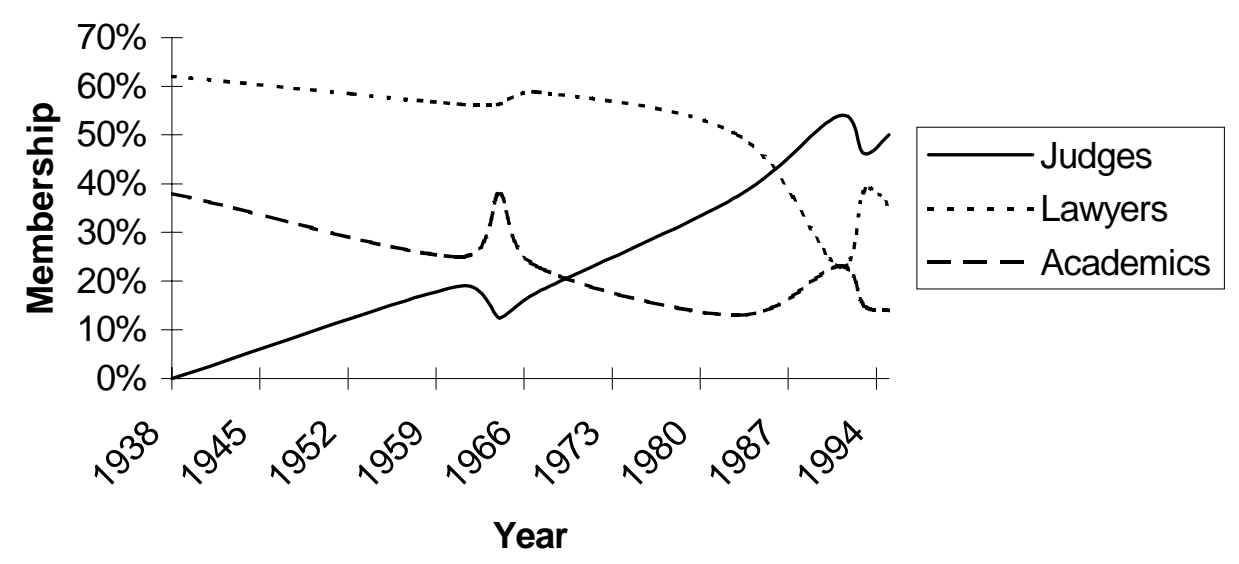

D uring this time, the proportion of legal academics on the A dvisory Committee ${ }^{40}$ has fallen in periodic spasms, from a high of almost forty percent in the early years to a current level ranging between fifteen and twenty percent. 0 ne could argue that the starting point was too high or that the low point is too low, but some academic representation is probably a good idea. A cademics provide both valuable scrivening services- the Reporter has always been an academic-and perhaps some degree of disengagement from the litigation wars. A cademics may also play a more disguised role. Though drawn exclusively from law schools and thus easily identified with the bar, in another sense these persons represent the public. Not directly engaged in litigation, they have some sense of how procedures will look to lay constituencies-parties, jurors, and the more general public. Though I lack either the objectivity or the data to support my conclusion, my sense is that these persons have played a generally constructive role, one that probably does not need fundamental rethinking.

IV

\section{A PROPOSAL}

The changes in structure and in personnel since 1938 might be desirable; indeed, at least one feature of the present process-increased transparency-is probably superior. But, with the best of intentions, we have also created for the judiciary and for the legal system some major problems. These are problems that lie in three rough categories- political, practical, and substantive. B oth as a thought experiment and as a proposal for discussion, I should like to examine the virtues of the 0 riginal Position: a two-step rulemaking process in which the

40. The Standing Committee came into being relatively recently, in 1958, so it does not provide a useful comparison, and the J udicial Conference has al ways consisted entirely of judges. 
earlier stages are dominated by lawyers, with judges asked only to approve the final result. The only change in the original position I recommend is the relocation of the final approving authority-from the Supreme Court, where it now resides, to the Standing Committee on Practice and Procedure. This proposal has several virtues to recommend it, as well as some objections that deserve discussion if anyone is persuaded by the virtues of the proposal.

A. Neutrality as J ustice, N eutrality and Politics

Politically, judges have two constituencies. Broadly seen, they serve the public. Narrowly seen, they must relate to the other two branches of government. Judicial domination of rulemaking runs risks with both groups.

A t a fundamental level, much of civil justice-particularly in the common law environment-depends on the parties' perception of the judge as neutralan arbiter of claims brought by the parties. In contemporary practice, we have enshrined that proposition by enforcing parties' agreements to arbitrate ${ }^{41}$ and allowing them to stipulate to facts known to be false, submit to unconstitutional assertions of territorial jurisdiction, ${ }^{42}$ and craft their own procedural rules. ${ }^{43} \mathrm{~A} \mathrm{I-}$ though each of these practices is subject to limits, each reflects a notion of consensual procedure not only as expedient but also as just. A s M irjan Damaska, writing in another context, put it: "From the Continental perspective,... [the A merican] judge would appear to be more like the moderator of a judicial conference, or perhaps a supervisor of fair proceedings, . . . rather than the quintessential decision maker." ${ }^{44}$

To be sure, judges taking such a stance might nevertheless write the procedural rules. B ut to have the rules themselves emerge from a group of once and future contestants-lawyers populating the advisory committee-provides a splendidly Rawlsian icing on the cake: ${ }^{45}$ Lawyers debating those rules have a deep knowledge of implications, but no precise knowledge of how those rules will affect them or their clients in any particular situation. To the extent that lawyers characteristically work for an identifiable kind of client (for example, injured individuals, insurance companies, real estate developers), the lawyers on the committee may have some guesses regarding the effects of particular rules. A s a group, defendants, for example, will likely favor more specific pleading standards, and plaintiffs the converse. But this prescience has limits:

41. See, e.g., Paul Carrington, ADR and Future A djudication: A Primer on D ispute Resolution, 15 REV. LITIG. 485, 493 (1996).

42. See, e.g., National E quip. Rental v. Szukhent, 375 U .S. 311 (1964); FED. R. CIV. P. 12(h)(1). From one standpoint, a defendant who has intelligently waived a jurisdictional objection has obviated any constitutional objection. However, in circumstances where an intelligent choice is virtually negated, the provisions of R ule 12(h) make it possible to "waive" the objection.

43. FED.R. CIV.P. 29.

44. Mirjan R. Damaska, The Faces of Justice and State Authority: A Comparative A PPROACH TO THE LEGAL PROCESS 39 (1986).

45. R awls describes his "veil of ignorance" as an effort "to use the notion of pure procedural justice as a basis of theory." J OHN RAWLS, A THEORY OF J USTICE 136 (1971). A pplying such a procedural theory to rules of procedure has a special justness about it. 
It is hard to say in advance whether expansive judicial powers over the pretrial conference, or expanded powers to reopen judgments, or more flexible deployment of cross-claims, or a requirement that judges write their own findings in bench trials will favor plaintiffs or defendants. To the extent that the ingrained bias persists, it can be addressed with careful composition of the committee itself. ${ }^{46}$

When judges rather than lawyers frame rules by which they will decide between litigants, judges open themselves to criticism and the perception of partiality. That perception becomes acute when the judge decides an issue under a rule that grants the court broad powers of discretion. ${ }^{47}$ When the judges have played a major role in writing such a self-empowering rule, the distress can become overwhelming. M any have noted that a keynote of the current $R$ ules is that they grant judges a very large degree of discretion. A t virtually every stage of the process-amendment of pleading, the "good faith" of a factual or legal investigation, advisability of reference to alternative dispute mechanisms, superiority of a class action, scope of discovery, severance and consolidation of trials- the R ules grant judges enormous discretion in the conduct and resolution of disputes. Consider, for example, recent rounds of amendments to R ule 16, dealing with pretrial conferences and settlement efforts. B oth the 1983 and the 1993 amendments expanded the range of judicial discretion to shape the case, urge settlement, employ "special procedures" instead of trial, and otherwise affect the outcome of a case, regardless of the wishes of the parties and their counsel. ${ }^{48}$ The wisdom of this practice is debatable. ${ }^{49}$ The point is rather that a rule expanding the discretion of judges would have much more force and legitimacy (if I may use that over-used term), if it had been drafted by a committee consisting entirely of lawyers, with a judicial body simply supplying an after-the-fact blessing. A s L on Fuller has noted, to have the contestants bestow discretionary power on an arbiter signals a high degree of trust. ${ }^{50}$ That trust is $^{-}$ correspondingly lacking when the arbiters bestow such power on themselves. When the committees producing such rules consist largely of judges, it gives additional ammunition to those who doubt the wisdom of enlarging judicial discretion in this sensitive area. If we hold the judiciary accountable-but not directly responsible-for procedural rules, judges will act more independently.

46. See infra Part V.A.

47. Compare J onathan R. M acey, Judicial Preferences, Public Choice, and the Rules of Procedure, 23 J. LEGAL STUD. 627 (1994) (arguing that judges will have an inherent preference for discretionmaximizing rules), with J anet Cooper A lexander, Judges' Self-Interest and Procedural Rules, $23 \mathrm{~J}$. LEGAL STUD. 647 (1994) (arguing that such an argument is overstated). Nevertheless, a noteworthy characteristic of modern procedural rules is the broad discretion that it accords to trial judges.

48. See generally FED. R. CIV. P. 16(c) advisory committee notes.

49. Compare J udith R esnik, M anagerial J udges, 96 H A RV. L. REV. 374 (1982) (condemning judicial efforts to "manage" rather than to try cases), with David Shapiro, Federal Rule 16: A L ook at the Theory and Practice of Rulemaking, 137 U. PA. L. REV. 1969 (1989) (approving broad discretion in pretrial phase).

50. See L on L. Fuller, The Forms and L imits of A djudication, 92 H A R V. L. REV . 353 (1978). 
The broad public and the subset of litigants and lawyers comprise one political constituency of judges. Judges also face a narrower yet more immediately powerful group: Congress. Practically speaking, Congress is the group with the power to call judges to account for their actions, including those pertaining to rulemaking. A s already noted, Congress has in recent decades been restive about both the process and the substance of various federal rules. ${ }^{51}$ From a structural perspective, such congressional restiveness is almost inevitable: A ny body or group exercising delegated congressional power will draw scrutiny and occasional critique from the delegator. Were the judiciary to remove itself from the actual drafting of the rules, some- though surely not allcriticism might diminish. A s things now stand, however, a proposed R ule starts out in an advisory committee on which typically half the members are judges, then proceeds through three additional bodies on which judges increasingly dominate, and culminates in the Judicial Conference and the Supreme Court, which, by definition, consist entirely of judges. U nder such circumstances, if Congress does not like something, the judiciary is the obvious group to blame, and the ensuing accusations harm judicial independence.

\section{B. Procedural Change and J udicial Vision}

Practicality as well as politics warrants the reexamination of the present judicial role in procedural rulemaking. O ver the last fifty years, the R ules have removed more and more of day-to-day procedure from judicial sight. Judges accordingly have less ability to assess the operation of rules of civil procedure than they did sixty years ago. D iscovery and settlement dominate contemporary A merican civil practice. ${ }^{52} \mathrm{O}$ ver these last sixty years, we have moved from a world of trials to a world of litigation, in which trials are a vanishing, some would say a pathological, event. ${ }^{53}$ More important than the disappearance of the trial is its cause. Kent Syverud, writing about the jury, recently captured the essence of A merican civil process, arguing that there is a trade-off between trial and pretrial process, and if we want more trials, we must be prepared to curtail the pretrial process. $^{54}$ Dean Syverud's equation captures the essential fact that U.S. civil litigation at the end of this century is dominated by its pretrial stage. ${ }^{55}$

O thers have, will, and should debate the desirability of this situation. For our purposes, the important point is that the vanishing of the trial has also removed the center of procedural activity from judicial eyes. A s that activity has

51. See supra text accompanying notes 28-33.

52. See, e.g., K ent D. Syverud, The D uty to Settle, 76 V A . L. R E V. 1112 (1990).

53. See, e.g., Kent D. Syverud, ADR and the D ecline of the A merican Civil J ury, 44 U CLA L. REV. 1935, 1944 (1997) (noting that "the civil jury trial appears to be an alternative for the freaks-an alternative to be avoided").

54. See id. (arguing that the "[c]ivil process must be streamlined, particularly in the expensive discovery stage, before the option of fact finding by a civil jury will appear viable-or preferable-to a significant fraction of civil litigants").

55. See Y eazell, supra note 17 , at 632-39. 
moved from judicial vision, it has become harder for judges to form accurate views about the practical operation of procedural rules. In typical litigation, ${ }^{56}$ a federal judge may rule on a preliminary motion on the pleadings, such as a jurisdictional challenge, will enter a scheduling order, and then hope that the parties do not misbehave too badly in discovery. If they do, and if the case finds itself on the motion calendar, perhaps after a preliminary tussle before a magistrate judge, ${ }^{57}$ the judge will have very little sense of the case's context. A s a result, the judge will be unable to determine whether this is an isolated episode of misbehavior by an otherwise cooperative party, or this is merely the visible tip of an iceberg, in which one party-or both-are pursuing a take-no-captives style of litigation.

B eyond this issue - of intense interest to the parties but not to rulemakerslies a more fundamental question: A t a general level, are the procedural rules working well? A nswering that question in 1938 might not have been easy, but because most procedure occurred in the courtroom, a district judge approaching it would at least have been able to draw on first-hand experience. B oth motions and trial practice did so by definition. A nd, until 1938, the little that occurred between those two points was not governed by rules of procedure. Today, most litigation activity occurs between those two points. A Imost perversely, we ask judges today to take an increasing role in shaping procedural rules, just as we have removed the bulk of procedure from the range of judicial vision. While that may not be madness, it is at least not an intuitive move. It would make sense if judges had comprised half of the 1938 A dvisory Committee but now assumed only a background role. It might make sense if the roles of judges and others had remained unchanged. It makes very little sense for judges to have assumed an increasingly dominant role in rulemaking even as the nature of civil process has moved out of the courtroom and into lawyers' offices.

\section{$\mathrm{V}$ \\ OBJECTIONSAND A DVANTAGES}

Congress and the Supreme Court would each have to act to carry into effect the change- or reversion to the original model-proposed above. ${ }^{58}$ To effect the changes suggested here would require, at a minimum, amendment of 28 U .S.C. § 2072(a), which vests promulgating power in the Supreme Court, and § 2073(b), which requires the Judicial Conference to supervise and approve the rulemaking procedure. M ore ambitiously, such a reform would also require re-

56. I exclude here the mega-case, in which the judge knows from early on that close supervision will be required.

57. Magistrate judges hear some 129,000 civil non-trial matters per year. See A DMINISTRATIVE OFFICE OF THE U NITED STATES COURTS, REPORT OF THE JUDICIAL CONFERENCE OF THE UNITED STA TES tbl. 16 (1992). In particular, discovery and other pretrial matters dominate this docket.

58. See supra Part IV .A.-B. 
casting of the transparency requirements now contained in $\S 2073$ (c) to provide appropriate substitutes for the current process. ${ }^{59}$

The Court's role would be simple to effect: It would have to change its recent practices. No statute specifies the composition of the Rules A dvisory Committee, but, as noted, recent practice has seen a majority or near-majority of judges and a judge as chair. ${ }^{60}$ The Court could achieve part of this change simply by replacing judges with lawyers as A dvisory Committee vacancies occurred.

Each of these changes would require some rethinking, taking of deep breaths, and self-abnegation by bodies that may not be most remarkable for these characteristics. I ask the reader-particularly the judicial reader-to postpone deciding whether such reconsideration is worth the effort until after considering first a pair of objections to such a change and then a pair of advantages. Suppose for a moment that Congress and the Court were prepared to consider these changes. Their merit would of course be the central topic of debate, but one can imagine subsidiary problems that might give pause to persons otherwise attracted to the idea. In order for a discussion to focus on the merits, I want to address those objections to reform, objections not trivial but also not fatal.

\section{A . Some Objections}

1. The Constitution and the Rules: Delegation. The Rules E nabling A ct delegates to the Supreme Court the power to make rules of practice and procedure. Although the wisdom of the delegation was vigorously debated, ${ }^{61}$ its legality was not. Perhaps because judges had immemorially made procedural rules, no one thought the issue doubtful. ${ }^{62}$ A nother reason for the absence of serious debate about the constitutionality of delegation may lie in timing. The R ules E nabling A ct was roughly contemporaneous with other $\mathrm{N} \mathrm{ew}$ $D$ eal legislation, some of which raised even more serious delegation problems.

The most telling comparison is with the $\mathrm{N}$ ational Industrial R ecovery $\mathrm{A} \mathrm{ct}^{63}$ portions of which were held unconstitutional in Schechter Poultry Corporation v. U nited States. ${ }^{64}$ These provisions in Schechter remitted to "trade or industrial

59. For a more extended consideration of the transparency issues posed by this proposal, see infra Part V.A.2.

60. See supra Part III.B.

61. Stephen Burbank's article is the classic account. See Stephen Burbank, The Rules E nabling A ct of 1934, 130 U. PA . L. REV . 1015 (1982).

62. Indeed, some have taken the more extreme position that only judges can make procedural rules. See, e.g., Linda S. Mullenix, Unconstitutional Rulemaking: The Civil J ustice Reform A ct and Separation of Powers, 77 M INN. L. R EV. 1283 (1993); see also supra note 9 (reporting a similar position taken by two state supreme courts).

63. Pub. L. N o. 73-67, ch. 90, 48 Stat. 195 (1933).

64. 295 U .S. 495 (1935). The other classical non-delegation case, Panama Refining v. Ryan, 293 U.S. 388 (1935), is less relevant to the rulemaking context because the Court's opinion emphasized the statute's contradictory vagueness, and not its remission of the decision to a group of arguably interested parties. 
organizations or groups" the framing of "codes of fair competition for the trade or industry," with enforcement of the ensuing rules vested in the federal district courts. ${ }^{65}$ The Court struck down this delegation, with the majority emphasizing the absence of procedural protections in the rulemaking process, ${ }^{66}$ and Cardozo's concurrence stressing the absence of standards for the contemplated codes. $^{67}$

Most contemporary scholars believe that the nondelegation doctrine is a phantom that ought to be of no concern to lawmakers or scholars. ${ }^{68}$ A s a descriptive and predictive matter, I am prepared to accept these verdicts. But there is another reading of Schechter that recalls Bentham's admonitions and which, even if it poses no legal threat to rulemaking, deserves consideration. By composing the original rules advisory committee entirely of lawyers and legal academics, the Court performed an act of delegation much like the type struck down in Schechter. In crude terms, it might be thought to have put the foxes in charge of the hen house. ${ }^{69}$ O ne can imagine Bentham's outrage: For him, perhaps the only solution worse than Judge and Company would be Lawyer and Company.

A ssigning to lawyers the responsibility for drafting rules by which litigation is to be conducted appears to be a form of guild corporatism at least as suspect as that in Schechter. Lawyers have two kinds of interests potentially at odds with the drafting of fair and efficient rules of procedure. First, they have the interests of their clients. A merican lawyers tend to represent, if not the same clients, then the same kind of client throughout their careers. ${ }^{70}$ To the extent to which it were possible to predict advantages from particular procedural rules, lawyer-rulemakers might favor their clients. Second, even without particular clients, lawyers are lawyers, and one need not have a dark view of human nature to imagine that they would draft rules that would favor their own interests.

The historical record might seem to bear out such worries. Looking with cynical hindsight at the sixty years since the promulgation of the Federal R ules, one can imagine a lawyers' conspiracy to drive up fees. Certainly the results support such a reading. A s a rule, law is cheaper than facts. We have produced a procedural system that runs on facts and is rich in ways for lawyers to produce- or resist production of-facts. M oreover, the R ules put lawyers rather than judges in charge of the fact-producing stage of litigation. M oving the essential stages of process to the front end of litigation, they also removed it from

65. Schechter Poultry, 295 U .S. at 539 n.4.

66. See id. at 542.

67. See id. at 551 (Cardozo, J., concurring).

68. See, e.g., Kenneth Culp davis \& RiChard J. Pierce, JR., Administrative Law TREA TISE 66 (3d ed. 1994) (observing that "[t]he Court has become increasingly candid in recognizing its inability to enforce any meaningful limitation on Congress' power to delegate").

69. In this respect, it also resembles the delegation to private parties struck down in Carter v. Carter Coal Co., 298 U.S. 238 (1936).

70. See generally JOHN P. HEINZ \& EDWARD O. LAUMANN, CHICAGO LAWYERS: THE SOCIAL STRUCTURE OF THE BAR 127-28 (rev. ed. 1994) (emphasizing the client differentiation of different segments of the bar). 
courtrooms to lawyers' offices. Judges rule on discovery only when the parties cannot agree, and, in spite of occasional complaints to the contrary, most cases proceed without significant disagreement ${ }^{71}$ - and thus without judicial oversight or knowledge.

In spite of these appearances, we should give lawyers a larger role in drafting procedural rules- at least so long as we adhere to a system that moves litigation away from trial and toward discovery and settlement. I so argue not because I believe that lawyers can be trusted to ignore their own and their clients' interest, but because I believe that careful selection of the advisory committee can largely balance clients' interests and that the alternatives to accepting the role of lawyers' interests are even less desirable. By eliminating judges from the drafting committee, it should be possible to neutralize client interests. Presently composed of fourteen members, the civil rules committee is large enough that with some thoughtful choosing, we (or, more properly, the Chief J ustice of the U nited States) can eliminate the more egregious forms of client representation. In spite of the fact that lawyers characteristically represent certain kinds of clients, lawyers cannot know certainly whether particular rules will play to client interests in particular cases. To the extent to which particular rules are inherently incapable of such trans-substantivity, one could ask whether they were appropriately promulgated under the provisions of the R ules Enabling A ct, which bars any rule that affects any substantive right. ${ }^{72}$ We can bolster this hope with thoughtful transparency practices, which are treated in the next section. ${ }^{73}$

In fact, by rendering the lawyers' interests more apparent and less disguised, we may improve our chances of emerging with an evenhanded policy. Practicing lawyers are wary of criticizing the federal judiciary, ${ }^{74}$ but they base their profession on criticizing one another, as do legal academics. So one might imagine a more robust debate within the advisory committee unencumbered by lawyerly deference for the life-tenured judiciary. O ne could do worse than defining evenhandedness and trans-substantivity as whatever emerged from a procedure in which all notable segments of the bar were represented and required to submit draft rules both to their colleagues and to an official approving body.

A t present, that approving body is the U.S. Supreme Court. For several decades, there has been a low key debate about whether the imprimatur ought to come from the Court or from some other group, with the Judicial Conference as the leading contender. This question is less important than resolving the problems associated with the Advisory Committee composition or the

71. See, e.g., D avid Trubek et al., The Costs of O rdinary Litigation, 31 U CLA L. REV. 72, 89-90 (1983) (finding a very low rate of discovery, little judicial intervention, and a high rate of settlement in modal civil litigation).

72. Federal R ule of Civil Procedure 23 might provide a test of this proposition.

73. See infra Part V.A.2.

74. J ohn Frank may be a notable, and noble, exception. See, e.g., J ohn P. Frank, The Rules of Civil Procedure-A genda for Reform, 137 U . PA . L. REV. 1883 (1989). 
number of steps in the process, but it is still worth addressing, particularly if we are contemplating change. A mong the groups that might have final approval authority, the Judicial Conference is probably the worst choice. The Conference typically meets twice a year for two days. A survey of Conference agendas over several decades reveals a crowded miscellany of items, ranging from air conditioning of courthouses to the assignment of visiting judges to judicial discipline. ${ }^{75}$ A s is appropriate for a body charged with judicial administration, the issues are heavily administrative. There is neither the setting nor the time for serious discussion of procedural rules. A body that lacks time for serious consideration of rules should not have a role in approving them. If we eliminate the Conference, that leaves either the Supreme Court or the Standing Committee on Practice and Procedure as possible approving entities. B etween these, I would lean toward the Standing Committee. ${ }^{76}$ The Court's prestige gives the Rules a powerful symbol of legitimacy, but a more serious danger outweighs that benefit. The Court has the ultimate responsibility of deciding whether a R ule, on its face or as applied, violates the R ules E nabling $A$ ct, with its prohibition against R ules that "abridge, enlarge or modify any substantive right." ${ }^{77}$ A s many have noted, the Court has never held any R ule to violate the A ct; J ustice $H$ arlan suggested that this circumstance flowed from the Court's initial approval of the Rules. ${ }^{78}$ If one believes that real judicial review of the Rules is desirable, the Court should not be the final approving body. ${ }^{79}$ Such real review would draw on the strength of the judiciary by giving it a genuinely judicial role in the rulemaking process. ${ }^{80}$

L awyers' client and guild interests are strong, but they are not insurmountable. More importantly, a well-designed rulemaking process will use lawyers' interests to overcome each other. I njecting judges into the process too early, as we presently do, risks truncating debate and involving judges prematurely in doing what they do best-deciding whether proposed rules are fair. E qually as bad, the current system involves judges in a debate with both Congress and the B ar over the transparency of the process leading to promulgation of the rules.

75. The agendas appear in A DMINISTRATIVE OfFICE OF THE UNITED STATES CouRTS, supra note 57 (agendas for Sept. 1945, Sept. and A pril 1954, Sept. and M ar. 1955, Sept. 1957, M ar. and Sept. $1961,1962,1965$, M ar. and O ct. 1970, M ar. and Sept. 1986, 1987, 1988, 1992).

76. The choice is not, of course, limited to these bodies. Charles $G$ eyh has proposed a permanent fifteen-person committee, with members drawn from all branches of government. See Charles $\mathrm{G}$ ardner $G$ eyh, $P$ aradise L ost, Paradise Found: Redefining the J udiciary's I mperiled Role in Congress, 71 N.Y .U. L. REV. 1165, 1234-49 (1996). Professor G eyh recognizes the concern that I have with this intriguing proposal. By inserting a step between the Judicial Conference and the Supreme Court, the new committee would add to rather than substitute for the existing process. That seems to be moving in the wrong direction. The proposal here set forth has the merit of both simplicity and experience of previous successes.

77. 28 U .S.C. § 2072(b) (1994).

78. See H anna v. Plumer, 380 U .S. 460, 477-78 (1965) (H arlan, J ., concurring).

79. The Chief J ustice might continue to appoint the members of the A dvisory Committee if it is thought that his appointment increases the likelihood of service.

80. The approving body-whether Court or Committee- should have the explicit power not only to disapprove a proposed Rule, but also to remand it with a statement of the concerns leading to remand. 
2. The Public, the Bar, and the Rules: Transparency and A ccess. O ver the last three decades, Congress has repeatedly questioned the rulemaking process. A Imost as regularly, Congress and the courts have cooperated in altering it. M ost of the alterations, though well intended, have been for the worse. They have vastly increased the number of steps in the process. They have led to ever-increasing judicial participation, further clogging the institutional arteries and taking ever-more judges away from their primary role-judging. But behind the congressional concerns and the resultant tinkering has stood one issue that deserves respect: the transparency of the rulemaking process.

The original A dvisory Committee and many of the committees that dominated the process through the early 1970s were very much old boys' clubs, which typically proceeded with a minimum of publicity and even notice of proposed rules. A lthough the persons in question were a distinguished lot, and we have much to be grateful for, the time has passed in which that form of elite dictation will be acceptable. Starting with the aborted Federal Rules of E vidence in 1974, Congress manifested increased criticism of the rules. W henever Congress dislikes the product of judicial rulemaking, it is likely to focus on the process leading to that product. A fter a series of hearings conducted by thenRepresentative R obert Kastenmeier, Congress passed the $1988 \mathrm{Judicial} \mathrm{Im-}$ provements and $A$ ccess to $J$ ustice $A \mathrm{ct}^{81}$ several portions of which required increased transparency in the rulemaking process.

M ost notably, these changes gave Congress and the public more time to decide what they thought of proposed rules and more information on which to base such a decision. Subsections (c) and (d) of 28 U .S.C. $\S 2073$ regulate the consultative process preceding presentation of a proposed $\mathrm{R}$ ule to the Supreme Court. The statutory hallmarks are notice, an opportunity for public comment, and an explanation of recommendations, including dissenting views. In other words, the rulemaking process itself has become proceduralized. The obvious model was administrative rulemaking, and the statute roughly approximates that model. Following this process, 28 U.S.C. § 2074(a) gives Congress six months to decide whether to disapprove a Rule, further specifying that the six months shall fall in a period where Congress is likely to be in session and to have an opportunity to raise objections.

The statutory motives are clear and laudable. They seek to achieve public comment and transparency of process, clarifying the motives and the debate over each proposed rule. M oreover, these statutory requirements could apply to the "new" rulemaking process here proposed. But a Congress prepared to make these changes ought also to be prepared to experiment with a more ambitious but less specific form of transparency.

The more ambitious transparency proposal would add to existing notice and comment procedures by requiring the Advisory Committee to formulate, for

81. Pub. L. N o. 100-702, 102 Stat. 4643 (1988) (codified in scattered sections of 28 U .S.C.).

82. With a possible exception for genuinely technical amendments, I have no quarrel with the six months afforded Congress. 
each set of proposed R ules, a plan that would actively involve a cross-section of the bar, specifically identifying those whose views might be adverse to the proposed rules. The Committee should decide the question of how best to elicit those views. Public hearings are certainly one way, but everything from web pages and email to targeted telephone interviews are another. The record of a rulemaking ought to include not just a list of those who commented, but a list of those contacted and the rationale for selection of persons and groups. $R$ ather than awaiting comment, the Committee might actively seek it, conducting interviews of persons with the requisite experience and thoughtfulness. $\mathrm{H}$ alf a dozen such conference calls, conducted by several members of the $\mathrm{A} d \mathrm{dvi}$ sory Committee, might simultaneously inform the drafters and increase awareness of pending proposals. Such targeted discussion would empower the committee actively to assume responsibility for wide circulation and broad soliciting of views. Such a role might serve the aims of publicity and transparency better than the current transcontinental junketing and often-desultory "hearings" at which there is little to be heard. A t best, they might transform the present hearings into focused opportunities to consider problems in a rule; at worst, they would provide a functional substitute for those hearings.

3. Reform and Stasis. A possible objection to removing judges from the process is the fear that the ensuing committee would be extremely cautious and consensus-oriented, and that we might thereby lose opportunities for real procedural reform. While this objection would be troubling if it were welltaken, history suggests that, if anything, the reverse is true. The original R ules, surely the single most substantial procedural reform in U.S. history, came from a judgeless committee reporting directly to the Supreme Court. The second most substantial set of changes came in 1966 with the joinder rules, which included the present class action rules. Whether one likes the results or not, one cannot see that committee as timid. $Y$ et lawyers and academics dominated it with only three judges (eighteen percent) on a seventeen-person committee. With a single notable exception - the now-defanged 1983 version of R ule 11judge-dominated, multi-step rulemaking processes have produced distinctly cautious rules. That makes intuitive sense. The judiciary is a generally conservative group, in the best sense of that word: Sweeping change is not the coin in which the bench trades. Moreover, with Congress breathing down the judicial neck in the last two decades, sweeping change might seem impolitic. ${ }^{83}$

O ne cannot be certain whether the composition of the committee, the increase in the steps of the process, or some other factor, like congressional concern, has been primarily responsible for the recent caution. If one were otherwise convinced that judges should dominate rulemaking, one could imagine a two-stage reform in which one first reduced the steps in rulemaking and later changed the personnel. Because there seem, independently of guesses about

83. O thers might add that sweeping change in some circumstances would violate the R ules $E$ nabling A ct, a sobering thought for any group of rulemakers. 
substantive effects on the rules, to be several strong advantages in removing the judiciary from the process, I would argue for compression and recomposition of the process at once.

4. No Role for Judges? A this point, anyone with a decent admiration for the achievement of the Federal R ules may be quite troubled. E ven if prepared to consider the advantages of a judgeless advisory committee, one might worry about the loss of judicial wisdom. The bench contains many people of great thoughtfulness, experience, and integrity. Barring them from rulemaking borders on the perverse. Fortunately, one can draw on that wisdom without incurring the disadvantages of the present system. Because judges remain accessible to the A dvisory Committee, one would expect that the Committee would call on judges actively, persistently, and regularly. Indeed, a welldevised consultation process could draw on more judicial voices than does the current one. Having judges speak is different from having judges draft. Second, if one gave to the Standing Committee the role of final approval of proposed Rules, one would have a group dominated by judges prepared to devote focused attention to Rules; concentrating authority is one way to have its wielders take seriously the responsibilities of power. Finally, if one removed the Supreme Court from the approval process, one would open the way to genuine judicial review; a group that had played no role in promulgating a $\mathrm{R}$ ule might well, in its judicial capacity, invalidate an occasional Rule, giving subsequent committees some sense for the meaning of "adbridge, enlarge, or modify." ${ }^{84}$

\section{B. Three A dvantages}

If these obstacles can be overcome, three advantages would flow from adopting the proposal sketched above. Two-saving time and reducing the judges' role in the politics of rulemaking-are implicit in what has already been said. The third advantage, the defederalization of the federal rules, has become an advantage only in recent years.

1. Time. A lmost every observer objects to the slow pace of the present process. Created in steps, each sensible from a short-range perspective, the totality is becoming a monster. A t one level, it is unfair to remark that the Constitution was drafted and ratified in less time than it takes to amend a Federal Rule of procedure. A t another level, the criticism is justified. A twoor three-step process will inevitably speed up the present twelve-step ordeal.

M oreover, such reform will conserve the scarce time and specialized skills of judges. We currently consume the time of forty-one state and federal judges on various advisory and standing committees responsible for the federal rules, and this number does not even include those on the Judicial Council. In some cases, because the time consumed with meetings, hearings, and the like is very

84. Rules E nabling A ct, 28 U .S.C. § 2072(b) (1994). 
considerable, the savings will be equally substantial. In other cases-as with the J udicial Conference-the time spent on R ules matters is slight, but in such instances it is all the more desirable that the process be shortened; the recent sorry case of the too-hasty rejection of a proposed draft of $\mathrm{R}$ ule 48 tells us that bad rulemaking can come just as easily from the expenditure of too little as from too much judicial time. ${ }^{85}$ The agendas of the J udicial Conference, loaded with twenty or more items at each of two day-long meetings, do not permit mature or thoughtful consideration of proposed rules.

2. Politics. The process here proposed reduces judges' involvement in the politics of rulemaking in two ways. First, by taking judges out of the groundlevel work of rule drafting, it helps to ensure that when Congress becomes annoyed with the product of rulemaking-as it inevitably will, from time to time-it will not direct its displeasure toward the federal judiciary. Nor will failures of the rulemaking process- of transparency or consultation-be laid at the judiciary's doorstep. Second, by reserving to the judges the final, virtually judicial, act of deciding on the overall fairness of a proposed rule, it should help to ensure not just the political acceptability but the real fairness of a rule. It is easier for judges to reject the work product of lawyers-they do that for a living-than it is for them to reject the work of their judicial brothers and sisters.

From the judiciary's standpoint, this feature has much to recommend it. In our system, it is sometimes necessary for the judiciary to cross swords with Congress or the Executive. It is desirable to minimize these occurrences and to confine them to only significant disturbances. Irritation with rules about service of process or the exclusion of psychotherapists from those permitted to conduct Rule 34 mental examinations do not fall into the significant category. From the standpoint of the judiciary, it is far preferable to have the lawyer chair of the A dvisory Committee on the congressional hot seat than it is to have a federal judge, no matter how judicious and prestigious. M oreover, one might predict that the number of times Congress will be interested in calling a lawyer or professor chair to sit on that seat will be more infrequent than the number of times it might seek to call a judge. First, to the extent that such hearings may sometimes mask a more generalized irritation with the judiciary, the tempting target will be removed. Such irritation is likely to be at its height when judges are legislating, which is just what they do when they draft rules. Second, "lawyers' rules" may be substantively less likely to draw congressional ire than "judges' rules" because judges may sometimes suffer from a tendency to think of themselves as still on the bench when framing procedural rules. By contrast, with the judges no longer part of the process, lawyers will have a very strong incentive to frame consensus rules, because that is the only way that they will get them through a committee of peers.

85. See supra text accompanying notes $21-22$. 
That incentive should be particularly strong when the committee has to present the package of proposed rules-stripped of any prior blessing-to a judicial body for its approval. ${ }^{86}$ R emoving judges from the A dvisory Committee removes the judiciary from clashes with Congress. Eliminating the present regime of approval by attrition may focus the advisory committee on its real task - which is not to get a set of rules past the next committee hurdle, but rather to frame an optimally evenhanded set of proposals for their first, and only, judicial consideration. Judges are good at judging. They are experts at evenhandedness. Taking them out of part-time legislation-procedural rulemaking-and instead letting them play a more judicial role in approving or disapproving the nearly final product will set better incentives for the advisory committee, reduce friction with Congress, and increase the likelihood that procedural change improve the current system.

3. De-federalizing the Federal Rules. The final advantage to removing the federal judiciary from the rulemaking process is that it will begin the process of defederalizing the Federal Rules. In 1938, such a prospect was nonsensical: The whole point of the enterprise was to create a distinctive, national, uniform procedural package for federal courts. Today, most litigation under the Federal Rules does not occur in federal courts. Some thirty-five states have adopted versions of the federal rules, and the litigation in such states swamps that in the federal courts, which handle only about two per cent of all civil cases in the $\mathrm{U}$ nited States. A s G eoffrey $\mathrm{H}$ azard recently commented, the Federal Rules have unintentionally created something close to a national procedure, based in the states but sharing enough state-to-state similarity to make it possible to talk about the system in a unitary way. ${ }^{87}$

A s a result of the states' adoption of the R ules, ${ }^{88}$ the A dvisory Committee now has the odd task of drafting rules whose major application will be in other jurisdictions. The present advisory committees have for several years recognized that situation by having a state court judge-generally from the jurisdiction's highest court- sit on each committee. But that gesture, though welcome, does not go far enough in de-federalizing and de-judicializing the drafting process. U nlike judges, lawyers cross jurisdictional boundaries. O utside governmental employ, it would be difficult to find many lawyers whose practice was exclusively federal. B ecause they cross those boundaries daily, lawyers have a better sense than federal judges as to how particular rules will play in state courts. Having identified a difference in application or result, the reconstituted advisory committee would face a difficult question: Should it draft a rule for its

86. I have suggested earlier the Standing Committee on Practice and Procedure. See supra text accompanying note 76. (1998).

87. See Geoffrey C. Hazard, Jr., From Whom No Secrets A re Hid, 76 TEX. L. REV. 1665, 1669

88. For our purposes, most of the states that have not formally adopted the R ules-for example, California, Illinois, New Y ork - have adopted such large portions of the R ules' central concepts, such as notice pleading, extensive pretrial discovery, and broad joinder, that even these Code states now essentially resemble a $\mathrm{R}$ ules regime. 
primary constituency - the federal courts- or for a larger, shadow constituency of state courts. But that is not a question that has to be answered univocally: O ne could draft a rule for the federal courts with notations about adaptations and variations for state circumstances. It would be at least odd and perhaps a violation of federalism principles for a group of federal judges to do such a thing. No such impropriety attaches to lawyers' expressing such views, even when the lawyers are appointees of the federal judiciary.

\section{VI}

\section{A Concluding Plea}

J udicial rulemaking does not leap to mind as a promising topic for a symposium on judicial independence and accountability. Of all the things that currently occupy the time of judges, the framing of procedural rules for civil cases must rank close to the bottom of activities thought likely to engender controversy or threaten judicial independence. Procedure is not in obvious crisis, and attacks on judges focus on decisions, not on rulemaking. In spite of this unlikelihood, judicial rulemaking warrants our attention. Historically, failed rulemaking has stood high in the list of accusations hurled at the common law judiciary, and the fate of the Bourbons awaits those who refuse to learn from history. But beyond historical caution lies a more specific threat: The success of the Federal Rules has masked what may be serious misjudgments about the rulemaking process itself, misjudgments that over time will embroil the judiciary in controversy and disrespect. If I am right about this second point, matters have recently gone from good to bad, with legislative changes exacerbating some errors of judicial administration.

In just over half a century, we have grown a remarkable number of encrustations on an originally lean process. M ore than encrusted, the process has also departed from its original design, pushing federal judges into circumstances for which they are less than ideally suited and in the process involving them in unnecessary congressional friction. If federal judicial time were an underused resource and if the present procedural system were still trial-centered, that judicial involvement might still be justifiable. But judicial time is scarce, scarcer than it should be. A nd we have removed process from the courtroom. Under those circumstances it is worth asking ourselves carefully and soberly about whether we are walking slowly down a primrose path-and whether a change of direction might not be advisable.

J eremy B entham disliked judges-or at least distrusted what he believed were their guild instincts. I do not share his views. But his focus on the interests, abilities, and blindnesses of rulemakers was characteristically perceptive. We should not be too proud to learn from the cantankerous political philosopher: J udges are better at judging than they are at rulemaking, and if we want to preserve judges' independence, we should not hesitate to confine them to their field of greatest comparative advantage. 